\title{
THE DOCUMENTATION OF HISTORIC MAPS OF WORLD HERITAGE SITE CITY SUZHOU
}

\author{
ZHANG Guangwei ${ }^{\mathrm{a},}$ \\ ${ }^{a}$ School of Architecture, Tsinghua University, Beijing, China - jane5times@gmail.com
}

KEY WORDS: Historic map, Suzhou, canal, spatio-temporal, geographic

\begin{abstract}
:
Documentation and analysis of historic maps enhance understanding of temporal and spatial interactions between events and the evolution of physical canals upon which they occurred. And the challenge of this work lies on carefully sifting of information through the maps drawn with relative accuracy by traditional cartographical principles before the emergence of scientific survey.

This research project focuses on sorting out the evolution of historic city Suzhou in a spatio-temporal view. The investigation was conducted through an in-depth analysis of historic maps. Re-projection of the geographical elements of the city to one single georeference, that is to say a standard map BASE, help acquiring an actual sense of the scale and facilitate the recognition of the city's evolution in clear details. It is an important contribution of this thesis in coordination of variously distorted geographical information contained in nineteen periods span from 1229 to 2013 into a single research resource.

Through the work both quantitative and qualitative, a clear vision of the evolution and characteristics of the urban structure of ancient Suzhou is achieved. Meanwhile, in the process of projecting the historical geometrical information onto the topographic map, historical bibliographic and cartographic records is key to the data coordination and readjustment, this inspire as well on the cautious utilization of historical materials from ancient time in the recording, documentation work.
\end{abstract}

\section{INTRODUCTION}

\subsection{Motivation}

The historic city Suzhou in China is famous for its world heritage-the classical gardens of Suzhou. Meanwhile, Suzhou gains its name as traditional water town for its marvellous double-grid structure of paralleled streets and canals, and history of which could date back to the $1^{\text {st }}$ century AD. This great achievement of urban planning was recorded in historical literature for generations and the earliest geographical proof is a map (the Map of Pingiian) engraved on a stele in 1229, the South Song Dynasty. In the map, the shape of the city, the moats, the structure of streets and canals etc. are clearly expressed and easy to figure out comparing to an aerial photograph of today. The only major change is the removal of an inner-city wall originally built to enclose the offices of civil government, and further detailed compare will unclose that the street-canal double grid structure of the city has been changed with the deterioration of waterways.

Through these two of almost 800 years difference in age, not only the deterioration of canals but a large number of scrappy changes has been undertaken concerning details of roads, gardens, residents, temples, public and official buildings and so on. The historic maps of the city later than 1229 till now, on the other hand, visualize geospatially the significant historical events in the life of the city.

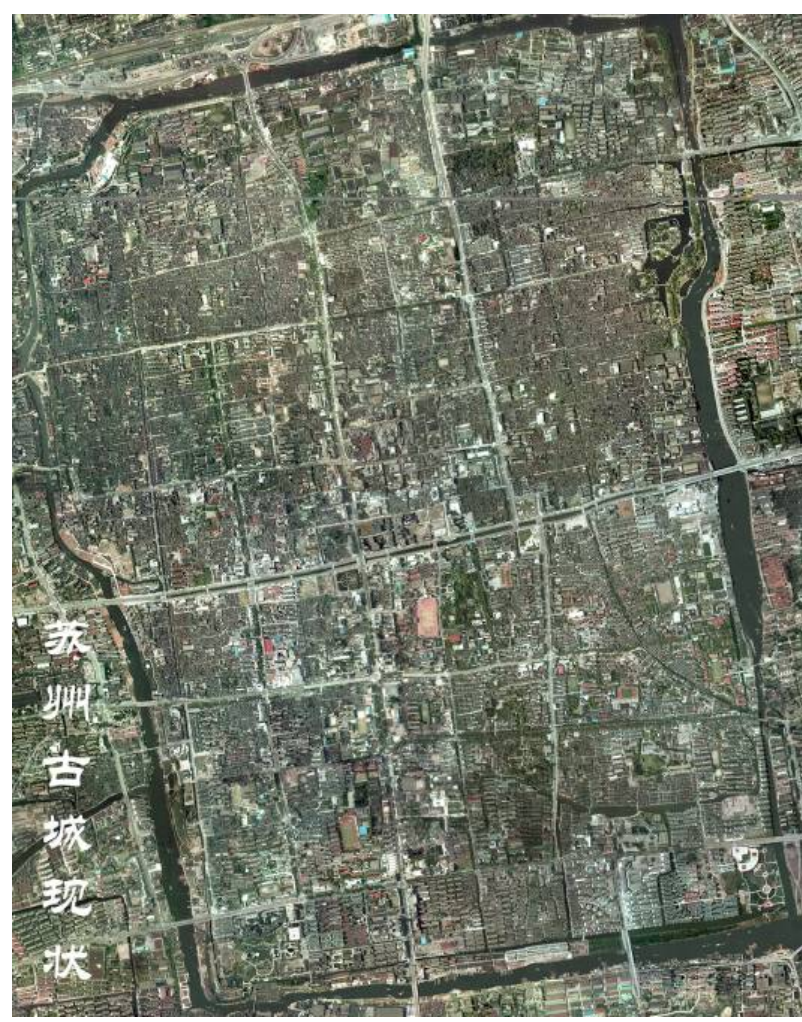

Figure 1. An aerial photograph of Suzhou in 2004

Data source: Chinese Urban Planning and Research Institute. 


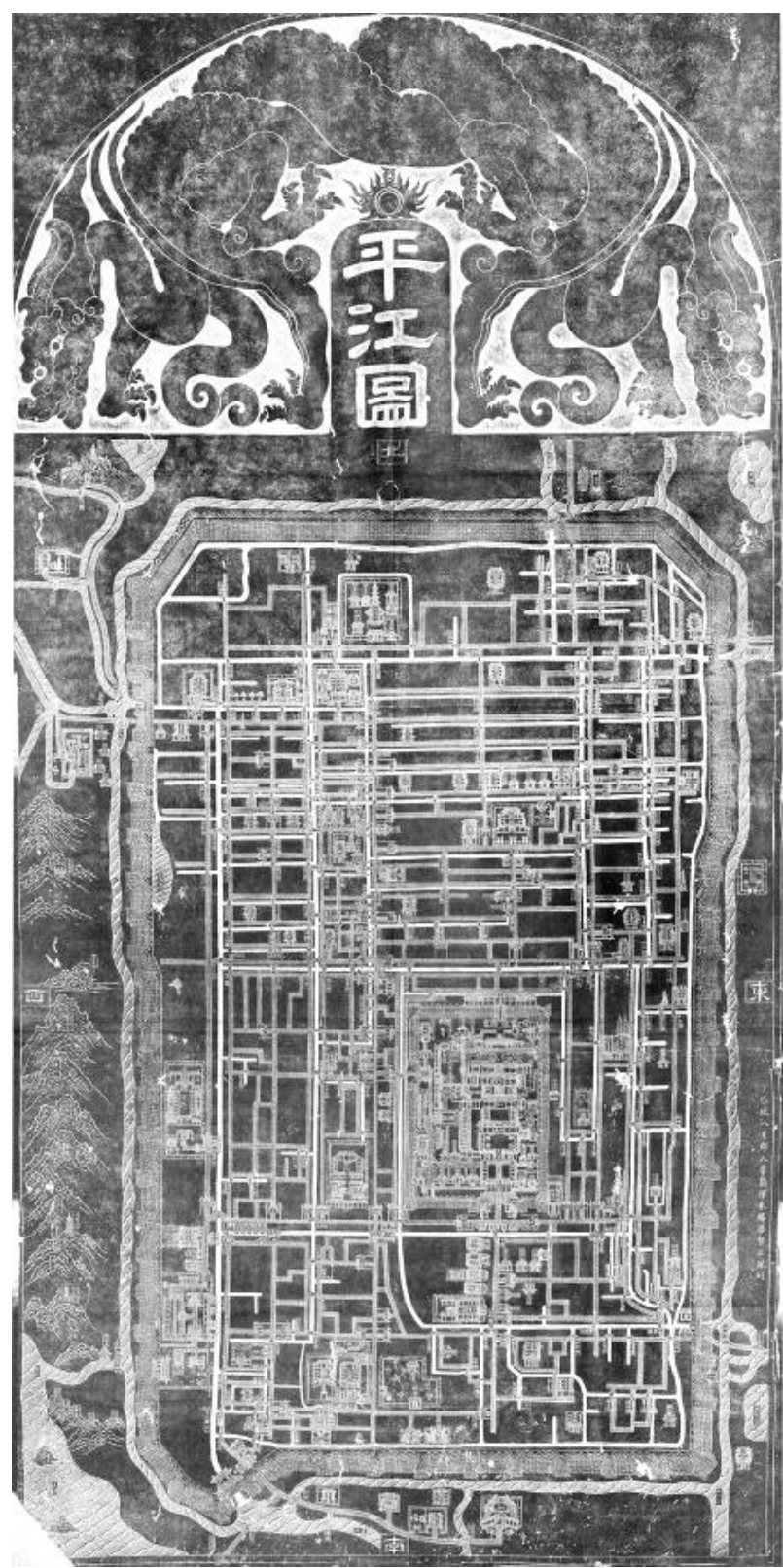

Figure 2. The Map of Pingjiang engraved in 1229.

Data source: (Zhang and others 2004.6);

\subsection{Aims}

This research project focuses on sorting out the evolution of historic Suzhou in a spatio-temporal view through documentation of historic maps; a great effort was taken on tracking the structural change of canals in this water town. Several researchers have done similar works from China and Japan. However, these works have never been unified and slightly differed with each other. Especially for those canals exist only in maps of 13-17th century, it is hard to trace them back from the current urban texture.

Thus it is an important contribution of this thesis in coordination of variously distorted geographical information contained in nineteen slices span from 1229 up to the present into a single research resource.

\subsection{Overview and references to related work}

In the historical Chinese document, crossed by bridges were usually used to describe the innominate canals on their lines and direction. In the case of Suzhou, we get to know that gazetteers have the tradition of recording the trunk watercourses marked by bridges. Those structural canals is called "San Heng Si Zhi"'(3 Latitudinal and 4 Longitudinal), for instance, according to Qianlong Gazetteer of Suzhou Prefecture.1748, the main 3 Latitudinal and 4 Longitudinal watercourse were recorded by bridges can be figured out as Figure 3 .

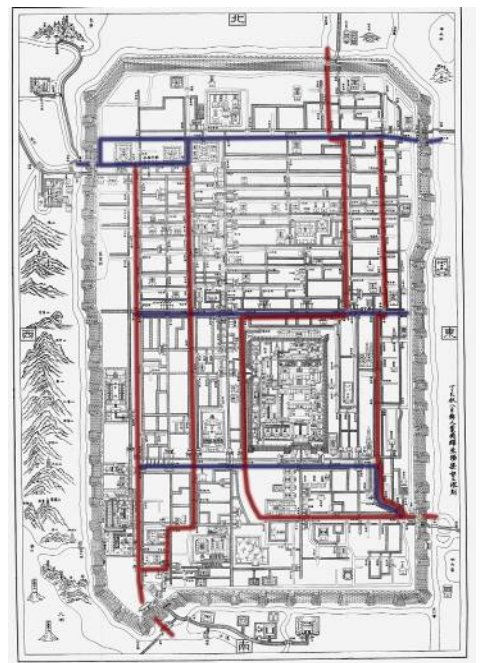

Figure 3. “San Heng Si Zhi” (三橫四直) 3 Latitudinal and 4 Longitudinal water courses in the Map of Pingjiang

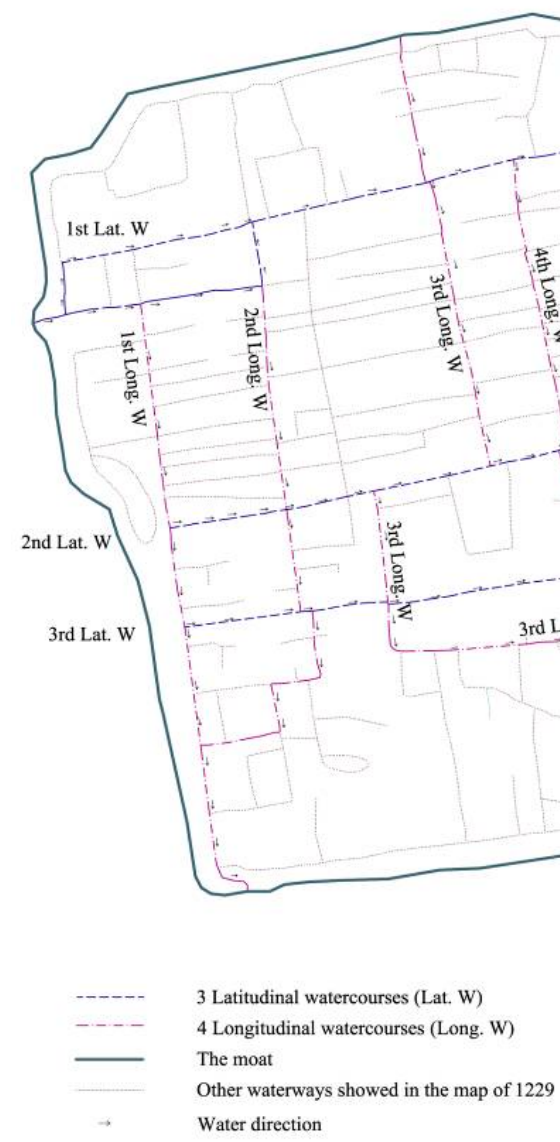

Figure 4. 3 Latitudinal and 4 Longitudinal water courses in a BASE map 
According to the historical maps and the records in the local Gazetteers, it is possible to make a roughly quantitative sense of waterways by period. Previous researches have given a general idea on the changes of waterways in Suzhou as showed in table 1:

\begin{tabular}{|c|c|c|c|c|}
\hline $\begin{array}{l}\text { Waterways of Suzhou } \\
\text { by Date (Period C/E) }\end{array}$ & $\begin{array}{l}\text { Lengt } \\
\mathrm{h} \\
(\mathrm{Km})\end{array}$ & $\begin{array}{l}\text { Amou } \\
\text { nt }\end{array}$ & $\begin{array}{l}\text { Bridg } \\
\text { es }\end{array}$ & $\begin{array}{l}\text { Variance } \\
\text { (Length/ } \\
\text { Amount) }\end{array}$ \\
\hline $\begin{array}{l}960-1279 \\
\text { Song Dynasty }\end{array}$ & 82 & 113 & 314 & \\
\hline $\begin{array}{l}\text { 1271-1644 Yuan- } \\
\text { Ming Dynasty }\end{array}$ & 86 & 121 & 340 & $\begin{array}{l}+4 \mathrm{~km} \mathrm{/} \\
8\end{array}$ \\
\hline $\begin{array}{l}\text { 1644-1911 } \\
\text { Qing Dynasty }\end{array}$ & 62 & 45 & 261 & $\begin{array}{l}-24 \mathrm{~km} / \\
76\end{array}$ \\
\hline $\begin{array}{l}\text { 1911-1949 } \\
\text { R.China }\end{array}$ & 47 & 30 & 169 & $\begin{array}{l}-15 \mathrm{~km} / \\
15\end{array}$ \\
\hline 1949-2006 P.R.China & 35 & 26 & 185 & $\begin{array}{l}-12 \mathrm{~km} / \\
4\end{array}$ \\
\hline
\end{tabular}

Table 1. Data of waterways by period in past researches coordinated by author

The first modern scholar who calculated the total length of the waterways in Suzhou inner-city was Zhang Yinglin, the editor of The Atlas of Ancient Suzhou (Zhang and others 2004.6). Followed by couple of others, at least six researchers have tried to figure out geographical information through several historical maps: Doctor Chen Yong made the analysis of waterways evolvement with the maps of year 1639 and 1896 adjusted on the base of 1229 Map of Pinjiang.(Chen, 2006.10) Hedaozhi(《蘇州河道志》) that documents the waterway system of Suzhou, especially, it coordinates the waterway and traffic grid from the historical maps of the years 1229, 1639, 1797, 1908 and 1940 (all of which are adjusted at the cartographic base of 1229 Pingjiang map); also the research conducted by professor Suzuki Mitsuro from Hiroshima University contributed the real scale adjustment of the map in the years 1229 and 1797.(Suzuki, 1992) And another researcher Yanli (YAN and others 2002, 249-252) completed the adjusted maps of the years 1639 and 1896. The Chinese researcher Dongwei(data from interview) and his student did the same work on the maps of 1639, 1745, 1872 and 1938. Wang Jin(Wangjing, 2006) from Dongnan University of China did similar works on the maps of the years 1229, 1639 and 1927.

\section{MAIN BODY}

\subsection{Methodology}

The investigation was conducted through an in-depth analysis of historic maps. Re-projection of the geographical elements of the city to one single geo-reference, that is to say a standard map BASE, help acquiring an actual sense of the scale and facilitate the recognition of the city's evolution in clear details.

\subsubsection{Quantitative Analysis}

Map rectification is the critical step to understand historical maps in the study of urban history when tracing back from a modern map is needed. There are two ways to attain this purpose: the first is to readjust the whole image of historical map by defining numerous points and relate the points to a relatively correct position in the GIS software; the second is manually redraw the information needed on the base of a modern map. With the former method, the taste and style of the initial map may remain, on the premise of allowable distortion and relatively authentic scale between the elements like road and water. Still, this operation calls for multi-readjustment. The latter one, however, is suitable for the seriously distorted ancient maps in which the ancients usually used to exaggerate certain elements of the city, like temples, bridges, or the waterways. However, as for exaggeration that generally constitutes style and taste, this will be more or less sacrificed.

Here in this research, manual redrawing is adopted. The working process followed these steps as below:

1. Extraction of useful geo-information.

2. Waterways projection on the relief map. (Available data by author was the 1:500 maps according to aerial photo in 1996)

3. Data coordination and readjustment

4. Analysis and synthesis by layering.

\subsubsection{Qualitative research}

A city, defined by Henri Lefebvre, is a projection of society on the ground. (Lefebvre 2006, 106) From what he took to be generic or defining characteristics of cities (size, density, and heterogeneity) we may derive the specific features of the urban "way of life", with theoretical respectability: archaeological traces.

There are two heterogeneous approaches to the enigma of profound lost historical truth of past, one moving along the path of retrospection on the basis of the experience principle of recognition, the other along the path of the internalization and appropriation of objective knowledge. (Ricoeur 2004, 412-418)

The section of qualitative survey will approach along the latter path to "seize" and assimilate a vanished past world which served to legitimate and celebrate. Concretely, the very state of a "reliving of images" of Suzhou's waterways history with the expression of vertical depth intervenes.

\subsection{Geographical Data acquisition}

As mentioned above the oldest map of Suzhou that exists now is the Map of Pingiian of 1229. Later ancient maps of Suzhou were founded either in chorographies, gazetteers or memorial stones like the Map of Pingjiang after great reconstruction of the city from war or dredging of the canals by the government. By far, the most valuable data source for this study was the archival collection of The Atlas of Ancient Suzhou (《穌州古城地圖》). This book compiled 19 historical maps of Suzhou from the earliest 1229 Map of Pingjiang engraved in stone in the Second Year of Shaoding's Reign of the South Song Dynasty, to the modern tourist map of 1949. Plus with other maps collected listed as the working base of this research as below in Table 2 .

\begin{tabular}{|c|l:l|l|}
\hline Code & Name of maps & $\begin{array}{l}\text { Date } \\
\text { Researched by } \\
\text { the author }\end{array}$ \\
\hline 1 & Map of Pingjiang & 1229 & $\bigcirc$ \\
\hdashline 2 & $\begin{array}{l}\text { Map of Waterways } \\
\text { Suzhou }\end{array}$ & 1639 & $\bigcirc$ \\
\hdashline 3 & Map of Gusu & 1745 & $\bigcirc$ \\
\hline 4 & $\begin{array}{l}\text { Map of Suzhou } \\
\text { reference) }\end{array}$ \\
\hline 5 & $\begin{array}{l}\text { The Map of Three } \\
\text { Latitudinal and Four } \\
\text { Longitudinal Watercourses } \\
\text { in Suzhou }\end{array}$ & $\begin{array}{l}\triangle \text { (re-adjusted } \\
\text { according to the } \\
1882 \text { map) }\end{array}$ \\
\hline
\end{tabular}




\begin{tabular}{|c|c|c|c|}
\hline 6 & Map of Suzhou Geography & 1864 & $\begin{array}{l}\triangle \text { (exceed the } \\
\text { allowable margin } \\
\text { of error) }\end{array}$ \\
\hline 7 & Map of Gusu & 1872 & $\begin{array}{l}\triangle \text { (not included } \\
\text { in the synthesis } \\
\text { calculation) }\end{array}$ \\
\hline 8 & Map of Suzhou & 1880 & $\begin{array}{l}\triangle \text { (not included } \\
\text { in the synthesis } \\
\text { calculation) }\end{array}$ \\
\hline 9 & A Complete Map of Suzhou & 1882 & $\begin{array}{l}\triangle \times \\
\text { (As reference to } \\
\text { the } 1888 \text { map) }\end{array}$ \\
\hline 10 & $\begin{array}{l}\text { Map of Suzhou City and Its } \\
\text { Ourskirts }\end{array}$ & 1888 & $\begin{array}{l}\triangle \text { (re-adjusted } \\
\text { according to the } \\
1882 \mathrm{map})\end{array}$ \\
\hline 11 & A Complete Map of Suzhou & 1896 & $\bigcirc$ \\
\hline 12 & $\begin{array}{l}\text { Map of Suzhou Patrol } \\
\text { District }\end{array}$ & 1908 & $\bigcirc$ \\
\hline 13 & Map of Suzhou Prefecture & $\begin{array}{l}1913 \\
17\end{array}$ & $\begin{array}{l}\times \text { (Almost same } \\
\text { as the map of } \\
1914)\end{array}$ \\
\hline 14 & $\begin{array}{l}\text { Newly Surveyed and } \\
\text { Detailed Map of Suzhou and } \\
\text { its Outskirts }\end{array}$ & 1914 & 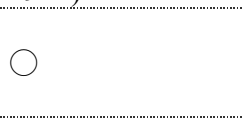 \\
\hline 15 & $\begin{array}{l}\text { The Latest Detailed Map of } \\
\text { Suzhou and its Outskirts }\end{array}$ & 1921 & $\begin{array}{l}\times \text { (Almost same } \\
\text { as the map of } \\
1914)\end{array}$ \\
\hline 16 & $\begin{array}{l}\text { The Latest Map of Suzhou } \\
\text { City }\end{array}$ & 1927 & $\bigcirc$ \\
\hline 17 & New Map of Suzhou & 1931 & O \\
\hline 18 & Map of 1930's & & $\begin{array}{l}\triangle \\
\text { reference Base) }\end{array}$ \\
\hline 19 & The Latest Map of Suzhou & 1938 & $\times($ Same as 1931) \\
\hline 20 & $\begin{array}{l}\text { Map of Wu County and its } \\
\text { Outskirts }\end{array}$ & 1940 & $\bigcirc$ \\
\hline 21 & $\begin{array}{l}\text { The Latest Map of Suzhou } \\
\text { Tourism }\end{array}$ & 1943 & $\bigcirc$ \\
\hline 22 & The Latest Map of Suzhou & 1949 & $\begin{array}{l}\times \text { (Almost same } \\
\text { as the map of } \\
1940)\end{array}$ \\
\hline 23 & $\begin{array}{l}\text { Relief Map of Suzhou } \\
1: 2,000\end{array}$ & 1958 & $\bigcirc$ \\
\hline 24 & $\begin{array}{l}\text { Relief Map of Suzhou } \\
1: 10,000\end{array}$ & 1972 & $\bigcirc$ \\
\hline 25 & $\begin{array}{l}\text { Map of Suzhou in current } \\
\text { status }\end{array}$ & 1985 & $\bigcirc$ \\
\hline 26 & $\begin{array}{l}\text { Relief Map of Suzhou } \\
1: 20,000 \\
\text { (CAD file) }\end{array}$ & 2004 & $\bigcirc$ \\
\hline
\end{tabular}

Adopted \& Adjusted; $\triangle$ Re-adjusted or as Reference; $\times$ not adopted in data analysis

Table 2. Comprehensive compilation of all the available maps in a chronology way

\subsection{Instrumentation}

\subsubsection{Initial map and BASE map}

Basically, once an initial map with most waterways was made, the others could use it, with additions and deletions representing the changed parts. As with most of the predecessors, this research also chooses the Map of Pingjiang as an initial rectification object.

The map of Pingjiang contains detailed information of waterways, roads, bridges, paifangs, temples, gardens and so on.
Some of them still can be found or the name been kept, although several canals disappeared for centuries, with those hints, re-positioning them become possible.

Generally, this research works are basing on the 1: 20000 relief map in CAD form (no. 25), and as for the name of street and alleys, and for the shape of earlier canals, a map of 1930's (no. 18) was referred, for its detailed marking of the site names which play an important role relating to the historical information; and also for its earlier survey date. Compare to all the other modern maps, it records more surviving canals.

\subsubsection{Problems and measures}

\section{Extent of tributaries without marks at the end}

As small single tributaries of the trunk canals have been disappearing for centuries, it is hard to pinpoint them with exact length above the modern texture if there are no marks like bridges or roads at the end of the canals. This is shown as follows on the juxtaposition of the same part extracted from the Maps of Pingjiang and the map of 1930's.

Concerning this kind of waterway, Yanli's rectification work shows high reliability, being drawn based on a modern relief map and having set those tributaries without end marks according to their proportion between the roads. Then his work on the Map of Pingjiang is adopted by this research as the starting basis. And a revision was made in this research - when putting Yanli's map on the map of 1930's, those ends of waterway are slightly adjusted to the nearby crossing, which according to the idea of this research, are supposed to be made in consequence or under the condition of the remaining watercourses.
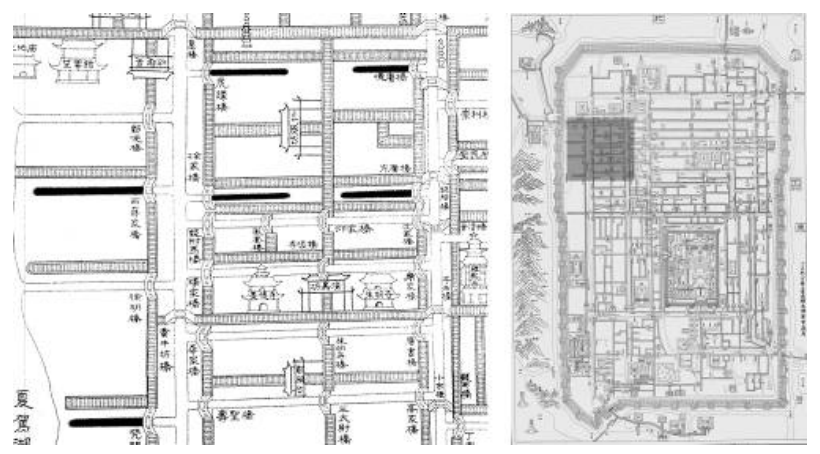

Figure 5. A part from the Map of Pingjiang showing canals without mark at the end (bold black lines)

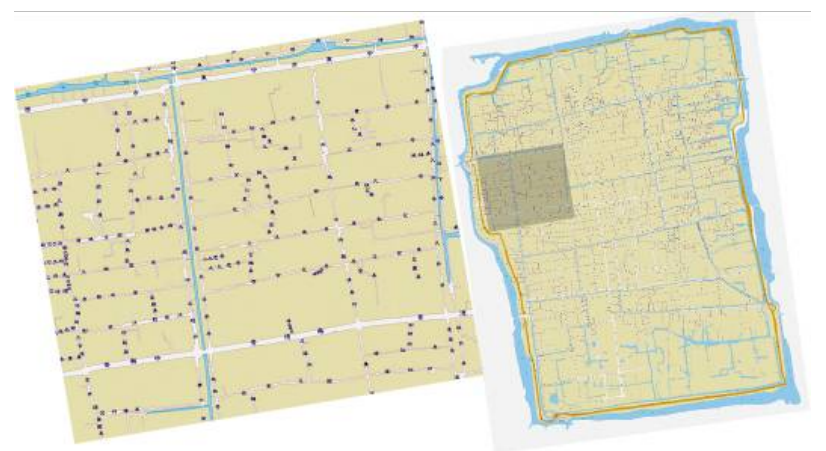

Figure 6. Same part from the map of 1930's. Almost all the canals lost. But those alleys became hint of the ends of those ever-existing waterways.

2. Shapes, widths and directions of tributaries in both the north and south parts of the city 
At the north and south parts of the city, waterways tend to be more irregular than the other orthogonal waterways in the central part. Most of these tributaries were initially for an irrigation purpose, and accordingly abnormal in shape, width and direction. Likewise, this is shown in the juxtaposition of the same part extracted from the Maps of Pingjiang and the map of 1930's.

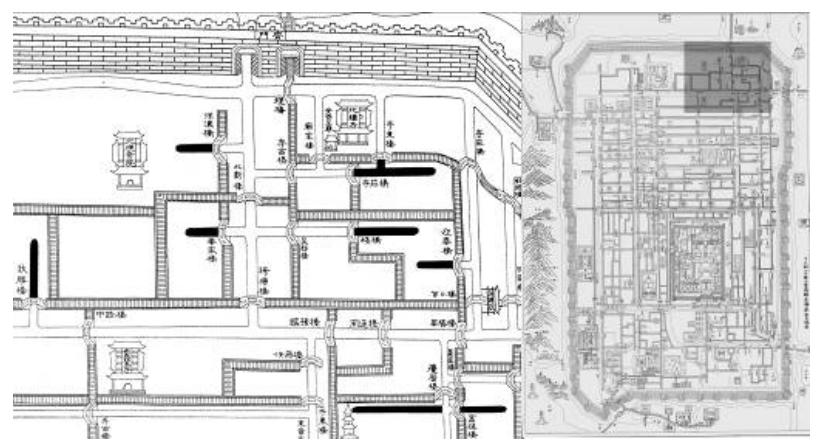

Figure 7. A part from the Map of Pingjiang in the north showing canals being initially for an irrigation purpose

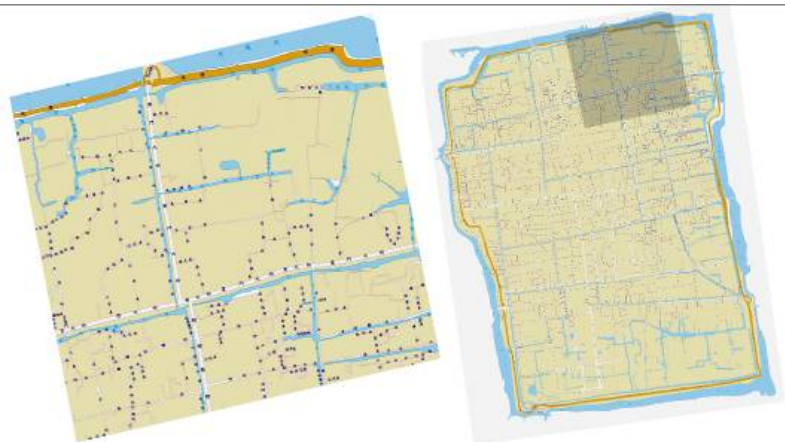

Figure 8. Same part from the map of 1930's. Showing waterways in irregular shapes, widths and directions

The strategy here is following the roads and exiting waterways in the map of 1930's. Furthermore, due to indistinctness of these tributaries, all the waterways in the final rectification works are draw with pure single lines of the same style as Yanli`s work. To this extent, the means are the same as previous, which is based on and revised according to the 1930's map from Yanli's work. However, even more revision was made concerning this part especially to those at the corner of the circumvallation.

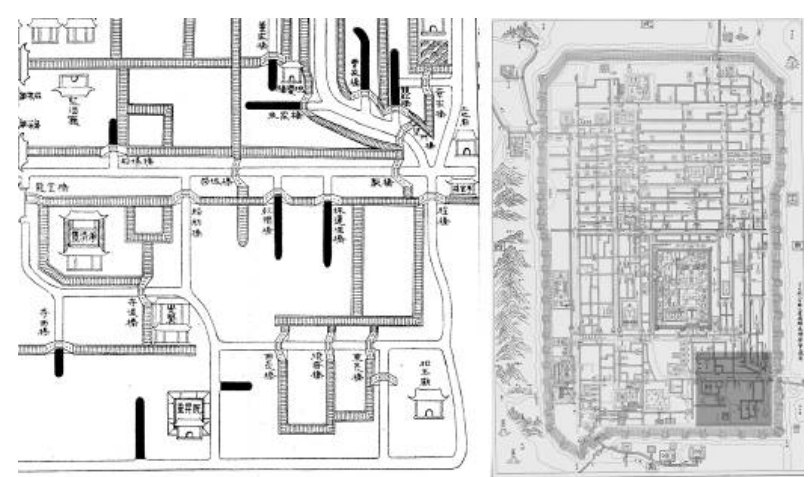

Figure 9. Another part from the Map of Pingjiang in the south showing canals being initially for an irrigation purpose.

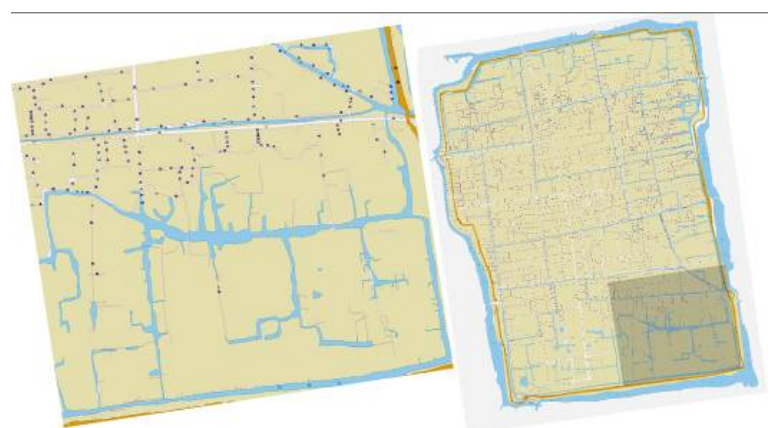

Figure 10. Same part from the map of 1930's. Showing waterways in irregular shapes, widths and directions.

\section{PROCESSING RESULTS AND DISCUSSION}

\section{1 "Archeaology" on Maps}

The first sketch starts from the year of 1229 , with combination of Yanli and Suzuki's waterway analysis been redraw into vector graph by this research, and projected on a rectified and rotated Map of Pingjiang, and the map of 1930's as well. All the text information on the 1229 map are transferred by hand writing to the 1930's map, including names of bridges, temples(Buddist and Daoist), Confucian temples(schools), pagodas, civic government, bureau of business, storages, military bar backs, paifangs and garden houses. Revisions are made during this 'map archaeology' process.

Besides transfer between upper maps, occasionally switches to a relief map of 1:500 (1990's) and 1:2000 (1958, map code 23) was done as well. From the latter two maps, detailed relationship between building and street and the invisible lost waterways could be understood farther. Take some parts as example as cases below:
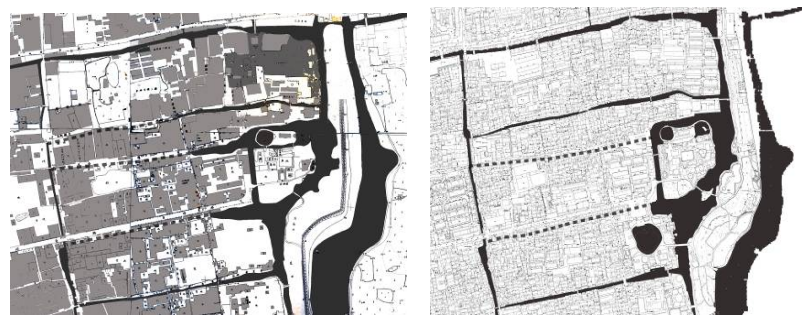

Figure 11. The waterways (filled in dark color) and routes that used to be waterways (dashed line) in the Dongyuan (東園) part near the east side moat in 1:2000 map of 1958 (left) and 1:500 map of 1990's.. 

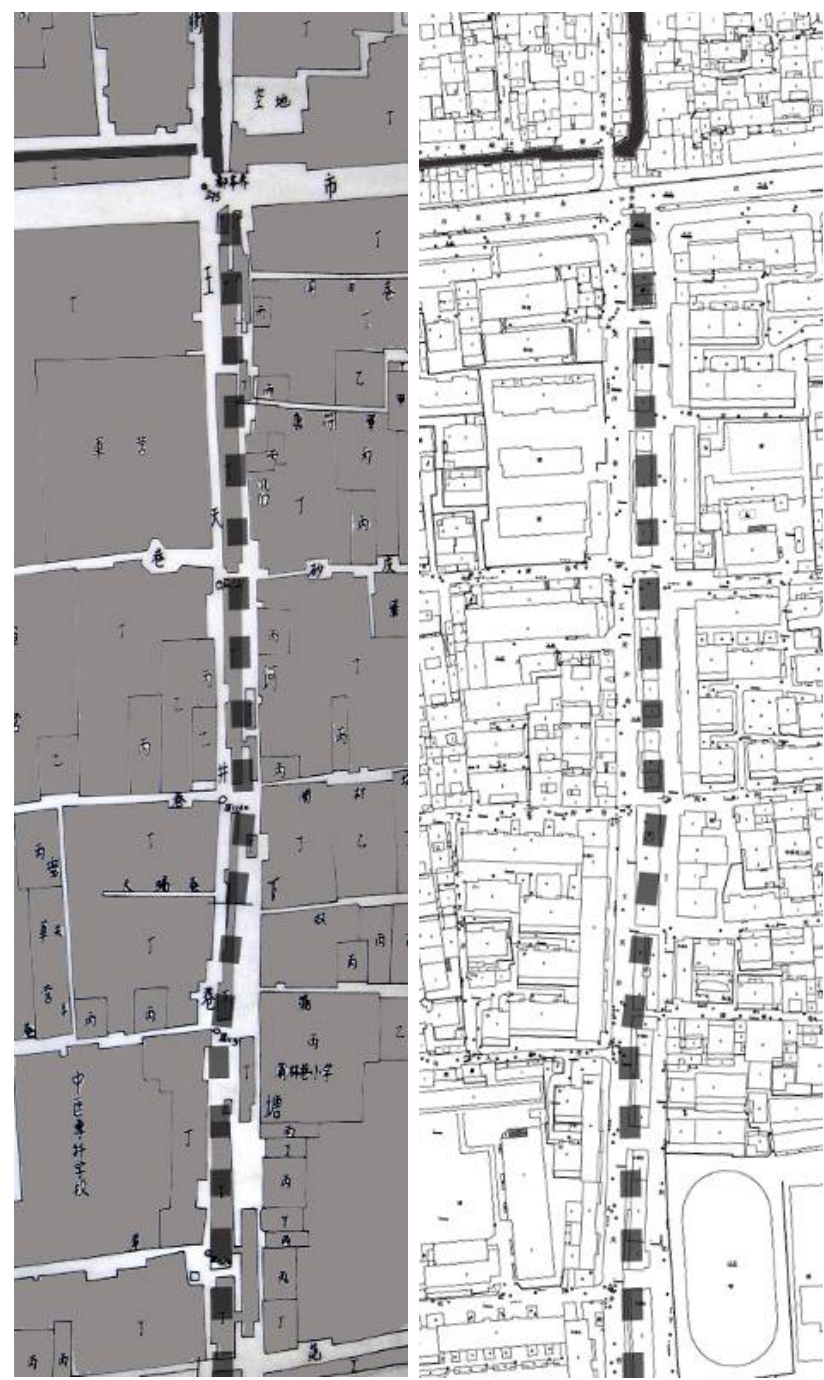

Figure 12. The waterways (filled in dark color) and routes that used to be waterways (dashed line) at the Wangtianjinxiang alley (王天井巷) in 1:2000 map of 1958 and 1:500 map of 1990 's. It used to be the $2^{\text {nd }}$ Longitudinal canal, where in the center, houses occupied the space of the lost water course.

\subsection{Processing and discussion}

3.2.1 Calculation of length: waterways are re-projected on an accurate relief map, wherein a total of 19 segments of waterway have been layered by years. These coordinated sources make further study on the characteristics of evolvement possible. Meanwhile, accompanied by a visual analysis of the waterway maps, a calculation of the total length will be made, giving a quantitative sense of changes. However, it is noticed that the years 1797, 1868, 1888 and 1930's are especially prominent in their difference with others.

\begin{tabular}{|c|c|c|c|c|}
\hline \multirow{2}{*}{ Code } & \multirow{2}{*}{$\begin{array}{ll}\text { of } \begin{array}{l}\text { Date of } \\
\text { map }\end{array} \\
1229\end{array}$} & \multirow{2}{*}{$\begin{array}{c}\text { Length of waterways } \\
\text { in the rectified } \\
\text { waterway map }(\mathrm{Km}) \\
91.0\end{array}$} & \multicolumn{2}{|c|}{$\begin{array}{l}\text { Increment compare } \\
\text { with the last map in } \\
\text { total length }(\mathrm{Km}) \text { and } \\
\text { per year }(\mathrm{m} / \text { year })\end{array}$} \\
\hline & & & NV & NV \\
\hline 2 & 1639 & 96.9 & 5.9 & 14.0 \\
\hline 3 & $\begin{array}{l}1743- \\
1748\end{array}$ & 68.4 & -28.5 & -268.0 \\
\hline 5 & 1797 & 51.2 & -17.2 & -330.0 \\
\hline
\end{tabular}

\begin{tabular}{|c|c|c|c|c|}
\hline 6 & $\begin{array}{l}1864- \\
1873\end{array}$ & 45.4 & -5.8 & -86.0 \\
\hline 7 & $\begin{array}{l}1872- \\
1881\end{array}$ & 58.9 & 13.5 & 1687.0 \\
\hline 8 & 1880 & 58.8 & -0.1 & -12.0 \\
\hline 10 & $\begin{array}{l}1888- \\
1903\end{array}$ & 48.5 & -10.3 & -1287.0 \\
\hline 11 & 1896 & 61.3 & 12.8 & 1599.0 \\
\hline 12 & 1908 & 63.1 & 1.8 & 150.0 \\
\hline 14 & 1914 & 63.4 & 0.3 & 49.0 \\
\hline 16 & 1927 & 65.1 & 1.7 & 130.0 \\
\hline 17 & 1931 & 61.5 & -3.6 & -899.0 \\
\hline 18 & $1930 ’ \mathrm{~s}$ & 70.3 & 8.8 & 2199.0 \\
\hline 20 & 1940 & 62.7 & -3.5 & -700.0 \\
\hline 23 & 1958 & 59.6 & -7.2 & -399.0 \\
\hline 24 & 1972 & 48.2 & -11.4 & -814.0 \\
\hline 25 & 1985 & 39.6 & -8.6 & -661.0 \\
\hline 26 & 2004 & 38.2 & -1.4 & -73.0 \\
\hline
\end{tabular}

Table 3. First Calculation result on the length of waterways based on the rectified maps (Note: The map 1930's is counted as 1935 when calculating the Increment per year. And other maps of ambiguity date are counted with the earliest year of span )

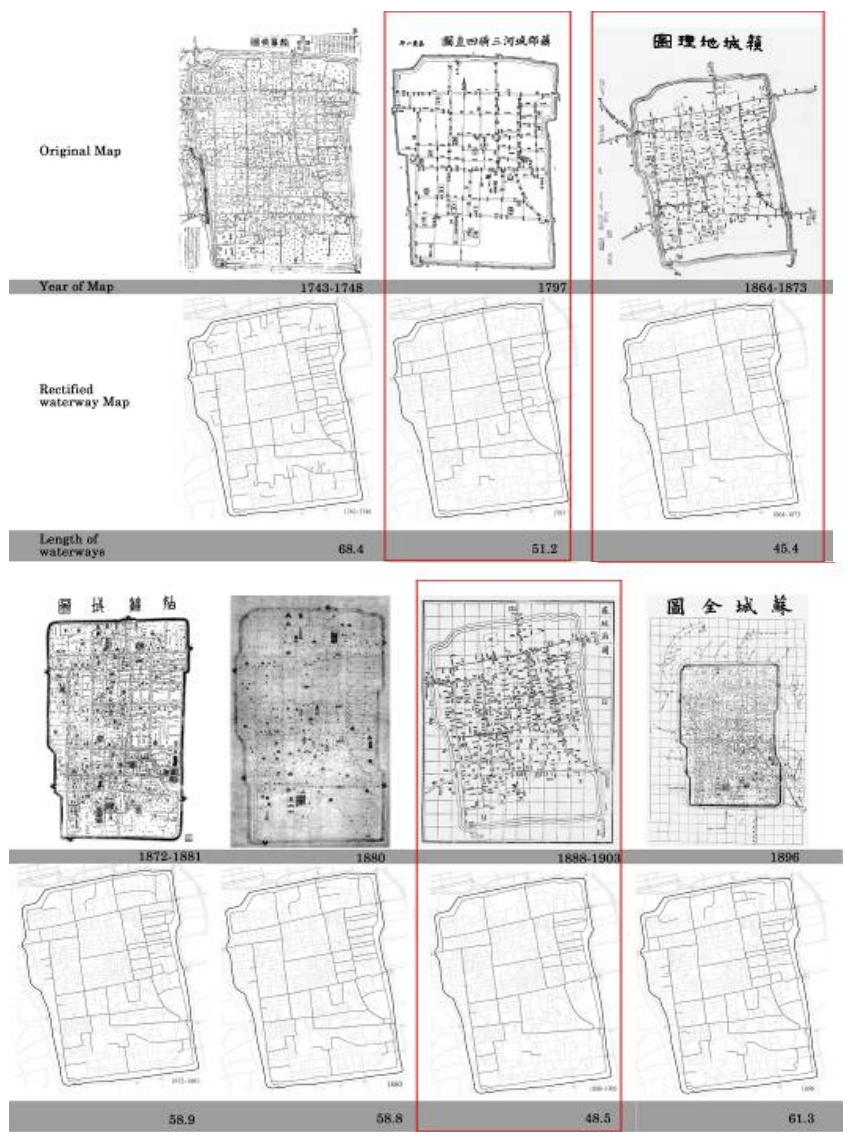

Figure 13. The maps and rectified waterways between 17431903. Map code 3, 5, 6, 7, 8, 10, 11 .

Canals from the maps of $1797,1864-83$ and 1888-1903 are especially less compared with the data of less than 50 years adjacent. In original historical maps, a part of the canals at both 
the south and north side of the city were left blank. Those areas were farmlands then, and it is possible that from the cartographers' viewpoint, the irrigation canals for agriculture were considered to be out of the spectrum of a city map. However, this is just an assumption and calls for further verification, which will be made in the following sections.

Another noticeable condition in the maps of 1864-83 and 18881903 is that two canals in the urban area were absent as well (a round one between the $2^{\text {nd }}$ and $3^{\text {rd }}$ Latitudinal canals and the eastern part of the $3^{\text {rd }}$ Latitudinal canal itself).

Meanwhile the 1930's map shows the opposite condition, an excessive depiction of the agricultural canals that makes this map extremely valuable compared to those of other years around the same time. As mentioned first, this map was treated as a reference foundation, so its data will not be counted in the next coordination and readjustment steps.

An in-depth search into the historical documentaries will be made in allusion to the unusual condition reflected in the 17971888/1903 maps.

3.2.2 Literature consulting: The misapprehension about Ming dynasty and the map of 1639

The Chinese have been in possession of sufficient documentaries in narrative form since long ago. Many more literal records remain about the condition of the waterways in Suzhou, which will be discussed further in section 3.4 with an analysis of the prominent decline. However, few detailed maps of Suzhou go with that literature. Here, they will be presented at first hand as reference.

Of all the Gazetteers available and referred by this research, the earliest map was shown in 洪武蘇州府志 Hongwu Gazetteer of Suzhou Prefecture (HWSZFZ.1379), but this map is an indistinct blue colour and lacking in detail, showing only the structural roads and landmark buildings. And it is very similar to the map in 正徳姑蘇志 Zhengde Gazetteer of Suzhou (ZDGSZ.1506). The condition of the map was even worse in 隆 慶長洲縣志 Longqing Gazetteer of Changzhou County (LQCZXZ.1571), with a very brief description and two plans of the civic government and the Confucian temple. This is understandable as it was just a partial gazetteer for a county that belongs to Suzhou city.

It was not until 真中水利全書 Wu-Zhong Shuili Quanshu (Documents on Water Conservancy in Wu) (WZSLQS.1639) that things got better. With the following 崇禎虽縣志 Chongzhen Gazetteer of Wu County (CZWXZ.1642), the style of the Map of Pingjiang was revived. Unfortunately, as it was a partial gazetteer for Wu county, we can see only the left part of the city map.

Following the gazetteer in 1642 is the Qianlong Gazetteer of Suzhou Prefecture (QLSZFZ.1748) and Qianlong Gazetteer of Changzhou County (QLCZXZ.1753). These two maps are almost the same, only differing slightly with a canal at the eastsouth block of Chang Gate (間門). From these two maps we get to know that there were numbers of waterways in both the northern and southern part of the city. Considering that the map of 1797 (map code 5) was carved on stone and the main focus was the 3 Latitudinal and 4 Longitudinal structural watercourses, a revision is made for those omitted main canals at the north and south parts.

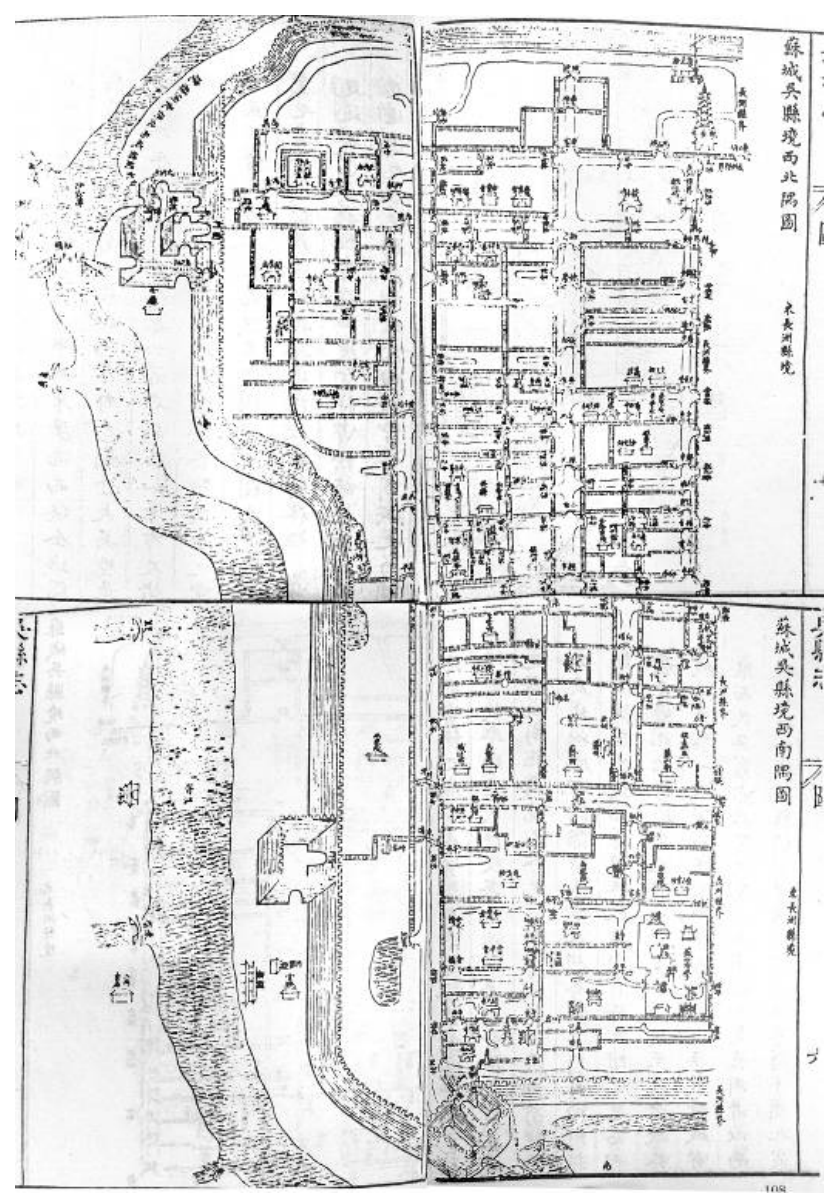

Figure 14. The map of Suzhou from 崇禎冥縣志 Chongzhen Gazetteer of Wu County. (CZWXZ.1642)

The map in 虽中水利全書 $W u$-Zhong Shuili Quanshu (Documents on Water Conservancy in Wu) (WZSLQS.1639) by Wang Guowei (王, 國維) is adopted in this research with map code No.2. This map was treated as a symbol of the golden age of waterways in history. As introduced in the last section where various maps illustrated the literature, the reliability is not always high, for omissions are common in the earlier years.

However, on the other hand, should we fully trust those maps with ample detail?

Wang Guowei wrote an explanation of the map that has been left unnoticed by most in posterity:

"The moats surrounding Suzhou are deep and wide so that different anabranches can converge. It narrows suddenly at Fengguan (封關 The Feng Gate). The waterways oriented from the south join into the Xujiang River (胥江) by a bridge. This strategic layout is set by the ancient prudently. Beside the main structural canals of 3 Longitudinal and 4 Latitudinal courses, which run from west to east and from south to north, the number of other canals inside the city exceeds hundred,. The canals were not silted up from Tang Dynasty to Song Dynasty and Yuan Dynasty. In our Ming Dynasty, they were dredged several times. Before Jiajing's reign (嘉靖 1522-1566, Ming Dynasty), the society was rich owing to the waterways in Suzhou. The canals went smoothly and the luck was good. The boats bearing faggots and paddy are driving trippingly through the canals. After Longwan's reign (隆萬 Longqing 隆慶, 15671572 and Wanli 萬曆, 1573-1620; Ming Dynasty), the 
management of the waterways was laid aside. Houses, trees and rubbish, gradually occupied canals, so that the shape of flow was changed. The west bank belonging to $\mathrm{Wu}$ county (吳邑) was flourishing while the east belonging to Changzhou (長洲) was flat. We learn from history that the canals are extraordinarily connected to the economic development. Many mistakes and omissions are found when reviewing the maps from existent gazetteers of counties. It is true that the city is too large to be recorded on a small piece of paper with all the canals described in detail. Here in this book, firstly the whole city as a master plan will be portrayed and marked with each administrant area of the two counties. Secondly, the city will be portrayed in four parts, describing the distances among the waterways and the ones between the bridges. The trace of rivers will be easily figured out according to the recording of this map even if they are silted up. I could not spare more effort for the sake of the waterways of Suzhou."
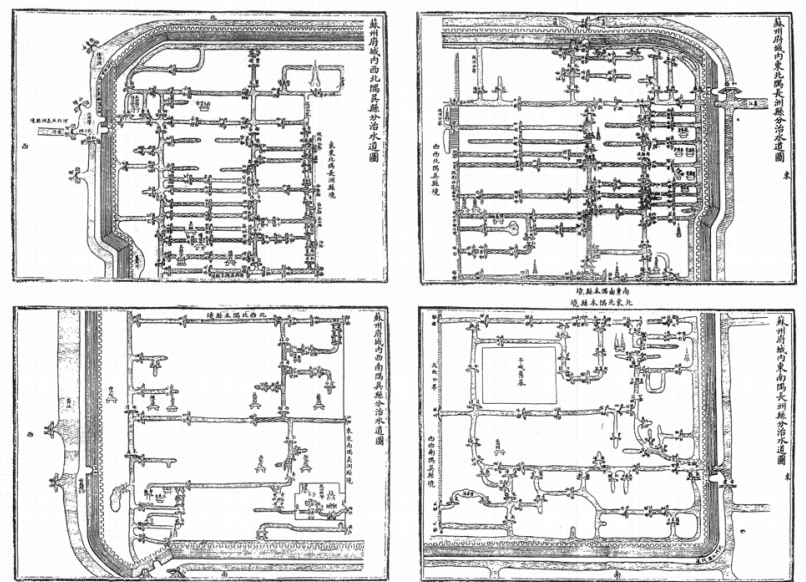

Figure 15. Original Map of Waterways in Suzhou, 1639, from 呈中水利全書 $W u$-Zhong Shuili QuanshuDocuments on Water Conservancy in $W u$ ). (WZSLQS.1639)

There are no other detailed map records available between 1229 (map code 1) and 1639 (map code 2), so we can hardly get to know the exact condition in those intervening 400 years. Usually it is thought that the waterways of Suzhou kept their prosperity during the Song (960-1279 AD) and Ming Dynasties, and that the decline started from the Qing Dynasty. However, at least from the author's narration we gain the fact that the waterway was experiencing a gradual silting up far before the year 1639 when the map was made, and even the author himself indicated that the purpose of this map was to leave as reference a complete record of waterways for the posterity in case of dredging.

\subsubsection{Re-inspection: maps coded $6,7,8$ and 10 :}

According to the textual research shown above, we can now come to the important standpoint that the historical maps were not always an accurate reflection of the conditions on the ground. For instance, the 1639 map shows the circumstances of an earlier period in the $16^{\text {th }}$ century. There was room for sketching more, or synchronously less, depending on the original intention of cartographers. Phenomena like this are especially evident with those maps drawn before the adoption of contemporary scientific cartography.

It is interesting to view the maps of 1864-1873 (map code 6) and 1888-1903 (map code 10), beside the omission of the agricultural canals, there were relatively less waterways even in the urban area where there were marked bridges without canals. Correspondingly, the lost canals appear in the two maps between them - the maps of 1872-1881(map code 7) and 1880 (map code 8 ). There were less than 8 years between the disappear-emerge, redisappear-reemerge process. We already know from textual records that the waterways had not been in a good condition due to continual disturbance from being occupied, blocked and polluted, along with increased population or the sudden destruction of war. The cartographers of map coded 6 and 10 may be truthful, it was highly possible that there was actually no water in the canals and they drew from the condition on the ground (except the agriculture canals at both the north and south ends of the city). When about 10 years later we see the steady return of the canals in the later maps from 1896 (map code 11), there must be a story of dredging behind it.

On the other hand, the map of 1864-1873 coded 6 was the first among all available maps that set the plan slightly acclivitous and adapted to the actual orientation, and the later map of 18881903 coded 10 was almost the same, also equipped with a grid and more detail. Both of these two utilized to a certain degree the cartography projection technique, and were supposed to be treated as maps of the scientific phase, or set out from an official purpose.

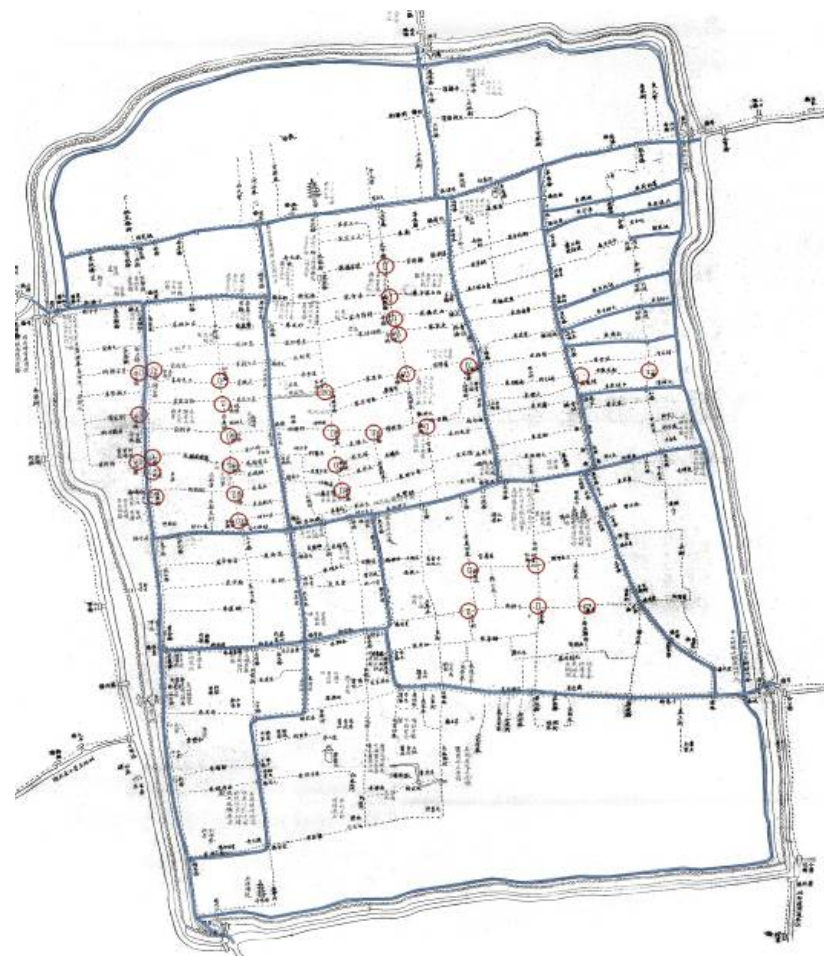

Figure 16. The map of 1864-1873 (map code 6), the red circles are marked bridges without canals.

The 1864-73 map (map code 6) is removed from the list of $2^{\text {nd }}$ calculation for its low deviance value. However, this doesn't mean it was not a correct map; it is just too truthful in its detail. Similarly, a map in the 光緒蘇州府志 Guangxu Gazetteer of Suzhou Prefecture (GXSZFZ.1883) presents the same attitude. 


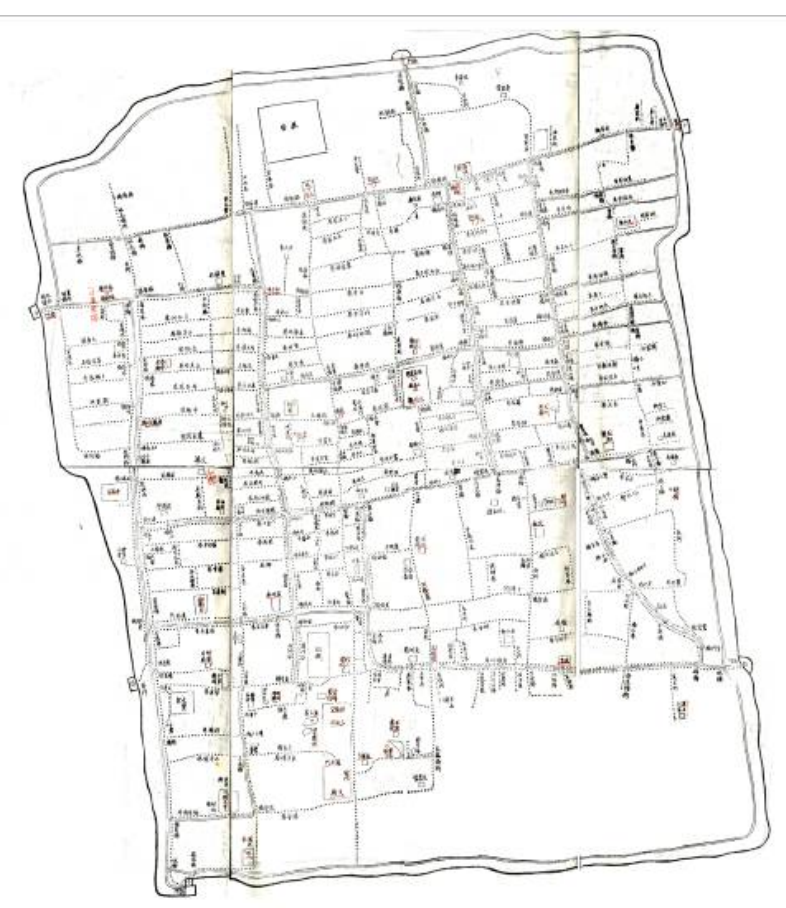

Figure 17. The map of Suzhou from 光緒蘇州府志 Guangxu Gazetteer of Suzhou Prefecture. (GXSZFZ.1883)

Nevertheless, should we call the cartographers of map 18721881(map code 7) and 1880 (map code 8) imprecise? If we review the maps again, it can be observed that:

First, geographically, these two maps are not as accurate as the other two coded 6 and 10 . They were drawn using traditional techniques and are more distorted.

Second, the famous sites such as temples, pagodas, gardens and even hillocks of ruin are illustrated with representative symbolic images. In contrast with the other two maps' scholarly appearance, these two tend to be more public oriented and intelligible.

Third, by the way the cartographers looked on canals to be perished, we can decipher a mood of sentimental wish that the canals exist, just as with Wang Guowei (王國維) who drew the map of 1639 .

3.2.4 Hints in the historical bibliographic and cartographic records: If we compare the map of 1639 with a later one in 1745 (map code 3), we find a clear and evident decrease in waterways in the central part of the city. However it is hard to trace back the story of each canal, for most of the tributaries had no name. Only one among them named Jinfanjing (錦帆涇) was recorded regularly in the volume of Water in gazetteers. However, from 正徳姑蘇志 Zhengde Gazetteer of Suzhou (ZDGSZ.1506), the later Jinfanjing (錦帆 涇) had ranged into the Relic volume (古跡) already, which means there was no canal, or at least no water in the course of Jinfanjing (錦帆涇)

More records before and around the $17^{\text {th }}$ century about Jinfanjing (錦帆涇) as well as the general condition of waterways that were occupied or silted up are cited as follows, and these support the conjecture that waterways declined from a year earlier than 1639 :
"Jinfanjing is a canal inside the city. It is said that the King of $\mathrm{Wu}$ sailed by boat in the past. The moat is still kept and fit for traffic of large boats. Some sections are occupied and blocked by the residences." (SDWJZ.1229, Vol. 18 Water)

"There is an old canal in the district. After its blocking, some gather and live near the bank. It is difficult to dredge again. In the $10^{\text {th }}$ year of Jiading (AD 1217), the sheriff named Zhao Yansu (趙, 彥橚) led the dredging from Jinfanjing in the four directions over a distance that totaled more than 1,100 Zhang (丈 unit of length, equal to approximately 3 and one third meters). It looked good after the dredging and recalled an old poem saying that "there are water chestnuts and lotus roots sold in the night market; there are some people in finery sailing in boats”. Xie, nan(謝, 南) wrote in the record of dredging again: "The Jinfanjing is to the west of the site of civic government, passing through Yueqiao, the rampart in the north and south sides. It is said that the king of $\mathrm{Wu}$ is sailing by boat along the road mentioned above. In Jiading $10^{\text {th }}$ year, Zhao Yansu (趙, 宸 橚) led the dredging and made it reach the Canal." (HWSZFZ.1379 Vol.3 Water)

"There are old canals around the inner-city called Jinfanjing. It silted up recently in mostly areas and there is only an old track in the east called Liaogu ..... Jinfanjing is the moat of the old inner city. It came from the story that the king of $\mathrm{Wu}$ sailed by boat. It runs west of the big street, passing through Yueqiao, the rampart in the north and south sides and reaching the Baoen temple directly." It does not only indicate the moat around the inner city." (ZDGSZ.1506 Vol.16 Relic)

"Lately in the city, there is no room for sailing on Jinfanjing. Zhao Yansu (趙,彥橚) is leading the dredging whose distance totals more than 1,100 zhang. Xie nan (謝, 南) is instructed to record that which does not exist now." (JJWYZ.1529)

\subsection{Data coordination and result}

With the historical survey presented above, some coordination and adjustment is made to the data of the $1^{\text {st }}$ calculation. For the $2^{\text {nd }}$ calculation, the addition of the omitted main canals is counted in and two extreme pieces of data been removed

1. The 1864-73 maps (map code 6) are removed from the list of the $2^{\text {nd }}$ calculation for its low deviance value.

2. The 1930's map (map code 18) shows the opposite condition with an excessive depiction of the agricultural canals that makes this map extremely valuable compared to those of other years around the same time. As a result, the data of 1930's is removed from the $2^{\text {nd }}$ calculation.

3. The maps of 1743-1748 (map code 3), the map of 1797 (map code 5) and the map of 1888-1903 (map code 10) were revised by adding the omitted main canals.

Furthermore, the extent of irrigation tributary details that differ according to the cartographers has an impact on the reliability of further analysis and comparative research. Since this research is focusing on waterways in an urbanized condition, finally the tributary irrigation canals are subtracted from the $3^{\text {rd }}$ calculation. Also, taking a stand from the viewpoint of scientific research, those sentimental plus as mentioned before, canals that actually had been running out of water or occupied will be removed from the $3^{\text {rd }}$ calculation as well. 
Changes for the $3^{\text {rd }}$ calculation are:

1. Tributary irrigation canals are subtracted from the maps of 1639 (map code 2), 1743-1748 (map code 3), 1797 (map code 5) , 1908 (map code 12) , 1914 (map code 14) , 1927 (map code 16) , 1931 (map code 17) , 1940 (map code 20) , 1958 (map code 23) and 1972 (map code 24)

2. The maps of 1872-1881 (map code 7) and 1880 (map code 8) are removed, as they were canals with no water, drawn by sentimental plus according to this research.

Based on the metric data until the $3^{\text {rd }}$ ones, a final synthesis calculation is made for the 16-17th century, namely the 1639 data (map code 2):

1. As discussed above, the most seriously lost canals in the central city actually show the condition of a century earlier, so their length will be subtracted from year 1639 .

2. A new date of 1500 (approximate number) will be added to the data of 1639 .

\begin{tabular}{|c|c|c|c|c|c|c|}
\hline $\begin{array}{c}\text { Code of } \\
\text { map }\end{array}$ & $\begin{array}{l}\text { Date } \\
\text { of map }\end{array}$ & $\begin{array}{l}\text { Date } \\
\text { for } \\
\text { analy } \\
\text { sis }\end{array}$ & $\begin{array}{c}1^{\text {st }} \\
\text { calculat } \\
\text { ion }\end{array}$ & $\begin{array}{c}2^{\text {nd }} \\
\text { calculat } \\
\text { ion }\end{array}$ & $\begin{array}{c}3^{\text {rd }} \\
\text { calculati } \\
\text { on }\end{array}$ & $\begin{array}{l}\text { synthesis } \\
\text { calculation }\end{array}$ \\
\hline \multirow[t]{2}{*}{1} & 1229 & 1229 & 91.0 & 91.0 & 87.8 & 87.8 \\
\hline & & 1500 & & & & 93.9 \\
\hline 2 & 1639 & 1639 & 96.9 & 96.9 & 93.9 & 79. 6 \\
\hline 3 & $\begin{array}{c}1743- \\
1748\end{array}$ & 1745 & 68.4 & 69.1 & 65.3 & 65.3 \\
\hline 5 & 1797 & 1797 & 51.2 & 58.3 & 57.3 & 57.3 \\
\hline 6 & $\begin{array}{c}1864- \\
1873\end{array}$ & NV & 45.4 & NV & & \\
\hline 7 & $\begin{array}{c}1872- \\
1881\end{array}$ & 1872 & 58.9 & 58.9 & NV & \\
\hline 8 & 1880 & 1880 & 58.8 & 58.8 & NV & \\
\hline 10 & $\begin{array}{l}1888- \\
1903\end{array}$ & 1888 & 48.5 & 54.4 & 54.4 & 54.4 \\
\hline 11 & 1896 & 1896 & 61.3 & 61.3 & 61.3 & 61.3 \\
\hline 12 & 1908 & 1908 & 63.1 & 62.8 & 62.0 & 62.0 \\
\hline 14 & 1914 & 1914 & 63.4 & 63.1 & 62.3 & 62.3 \\
\hline 16 & 1927 & 1927 & 65.1 & 64.7 & 63.6 & 63.6 \\
\hline 17 & 1931 & 1931 & 61.5 & 61.5 & 59.5 & 59.5 \\
\hline 18 & 1930' & NV & 70.3 & NV & & \\
\hline 20 & 1940 & 1940 & 66.8 & 66.8 & 60.8 & 60.8 \\
\hline 23 & 1958 & 1958 & 59.6 & 59.6 & 53.8 & 53.8 \\
\hline 24 & 1972 & 1972 & 48.2 & 48.2 & 43.4 & 43.4 \\
\hline 25 & 1985 & 1985 & 39.6 & 39.6 & 39.6 & 39.6 \\
\hline
\end{tabular}

\begin{tabular}{|c|c|c|c|c|c|c|}
\hline 26 & 2004 & 2004 & 38.2 & 38.2 & 38.2 & 38.2 \\
\hline \multicolumn{7}{|c|}{$2^{\text {nd }} \backslash 3^{\text {rd }}$ Calculation on the length of waterways: } \\
\hline \multicolumn{7}{|c|}{ Red: Adding of omitted canals' length } \\
\hline \multicolumn{7}{|c|}{ Green: Removal of irrigation tributaries' length } \\
\hline \multicolumn{7}{|c|}{ Orange: Synthesis calculation of the 16 th -17 th century } \\
\hline
\end{tabular}

\subsection{Visual presentation}

The waterways involved in the $3^{\text {rd }}$ re-calculation are figured out with colors in the maps as shown here. The red lines are the adjusted waterways supposed to be omitted by initial cartographers of the maps made in the years 1743-1748 (map code 3), the map of 1797 (map code 5) and the map of 18881903 (map code 10). The green lines are tributaries of supposed irrigation waterways that length of which been removed from the 3 rd calculation..
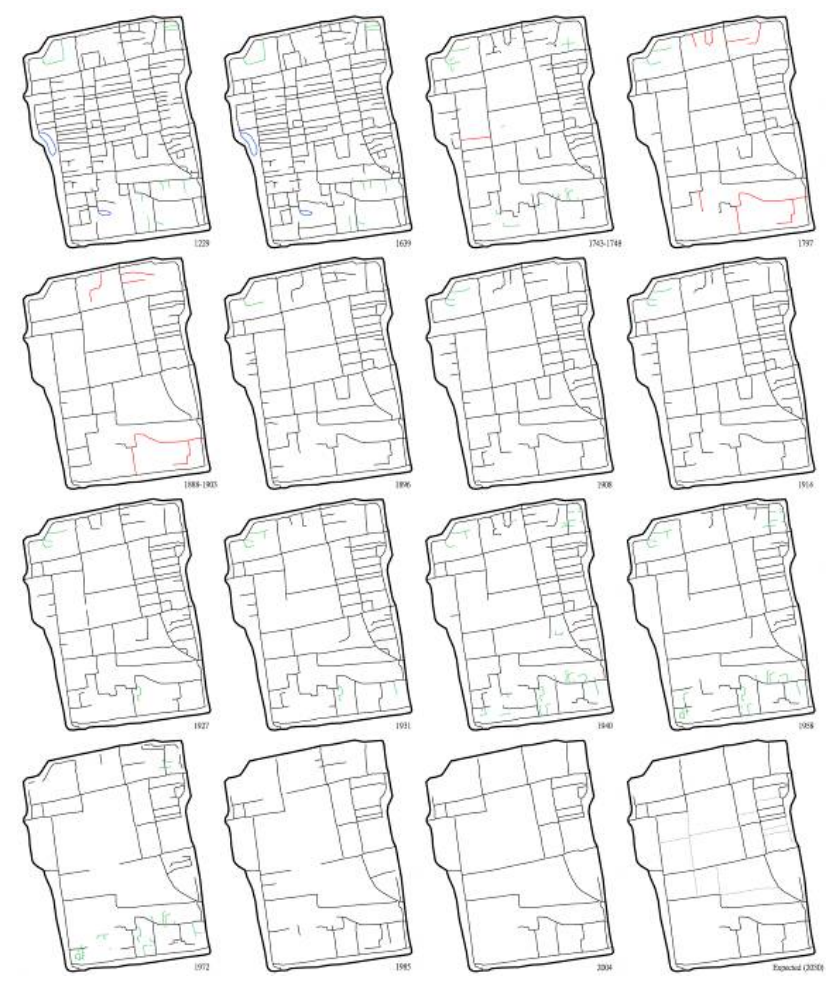

Figure 18. E

\section{CONCLUSION AND FURTHER WORK}

\subsection{Spatio-temporal evolvement}

The synthesis calculation at the forth stage, as a conditional examination, is the main of production of this research. From which, we could deduct a further review that the declining experience of Suzhou's waterways was most dramatic in two periods: the $16-18^{\text {th }}$ century and the $1950-80$ 's. And the characteristic of these two periods is definitely different.

On space surface, the first period is centred, and the latter, scattered, while in time scale, they are defined by this research as "Chronic Decrease" and "Disruption", as showed in figure 18-19. 


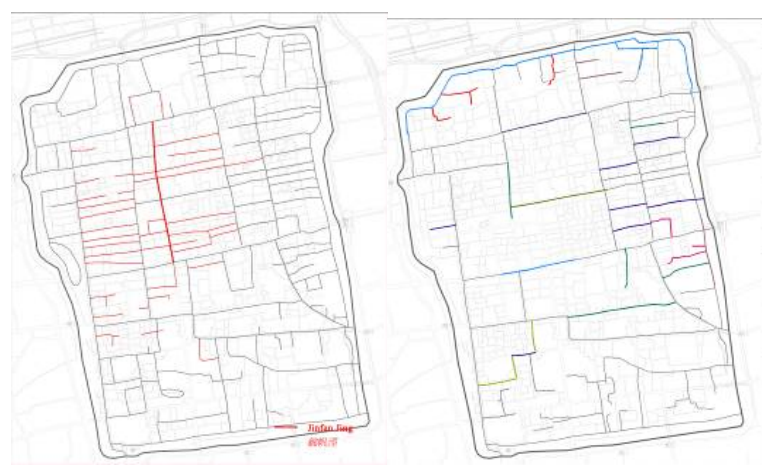

Figure 19. Evolvement of the waterways on spatial distributeon Left: Most dramatic lost waterways during the $16^{\text {th }}-17^{\text {th }}$ century; Right: Most dramatic lost waterways during the 1950-80's

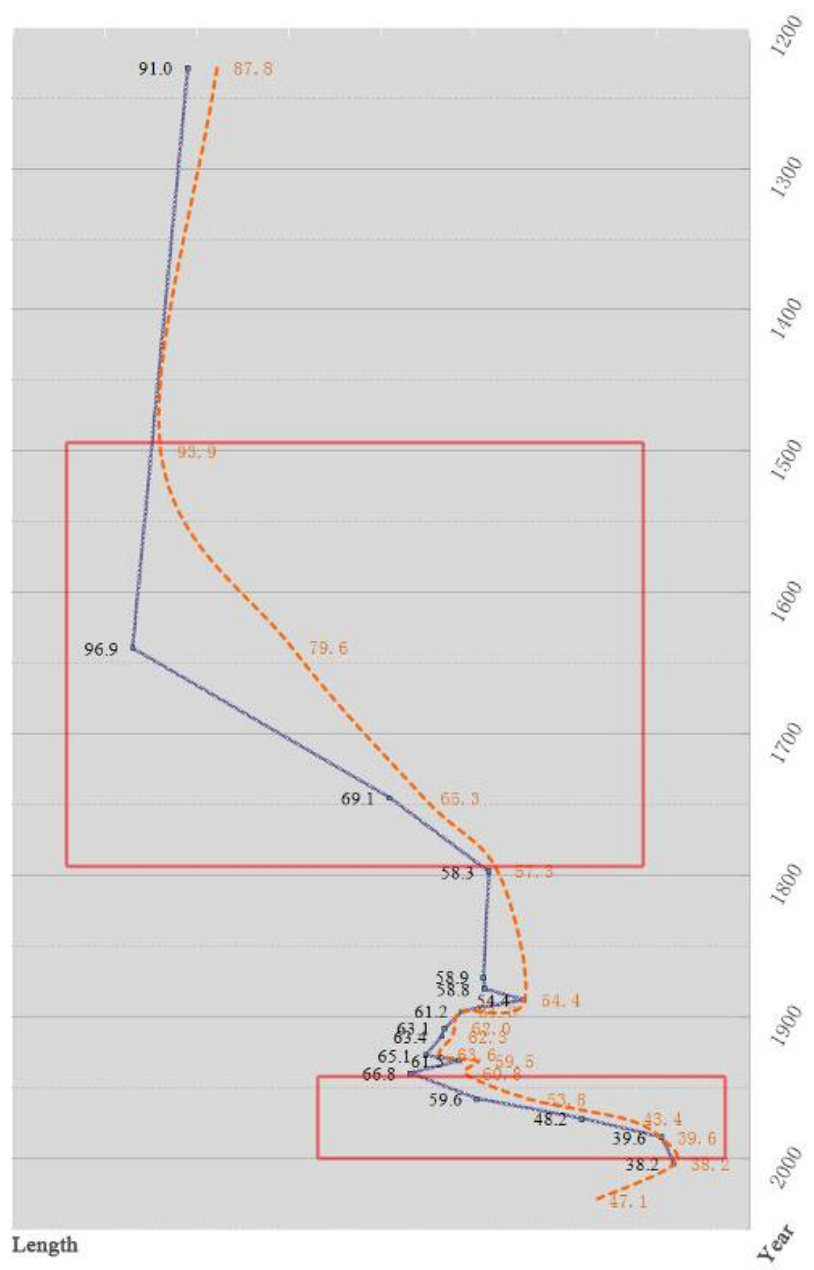

Length of the waterways on 2nd calculation

---- Curve of the waterways variation on synthesis

Figure 20. Diachronic evolvement of the waterways

\subsection{A Dialectic Inspection of Historical Map}

Historical maps give the modernist an eye though time to the past, revealing traces of vicissitudes in one place. Still, as experienced in this research, the pre-modern maps, namely maps before scientific cartography, give a greater possibility of "sentimental plus". The historical maps were not always accurate reflections of conditions on the ground.
For instance, it is accepted that the 1639 map from the Wuzhong Shuili Quanshu stands for the florescence of the waterways in Suzhou, and it is the reason most people presumed that the Ming Dynasty is still Suzhou's golden age as a water town. In fact, as cited in Chapter Three from Wu-zhong Shuili Quanshu, the book where the maps are recorded and other literature of the same period, it could be found that actually a large number of the waterways drawn in the maps were already dried up. Another of the interesting phenomena shown in the later maps is that some bridges were drawn in the street although there were no waterways underneath. It precisely displays the process of evolvement of the waterways in Suzhou in decline: stagnated, fouled and silted, along with the process, attenuated by residential buildings, and then there came the war and depredation accelerated the desolation of the canals. As traces of the waterways, the bridges were finally removed, then the memories of the once existing waterways became a paperbased fact undiscovered by the mass of next generations.

Another example is the contradiction seen in the maps of 18721881(map code 7) and 1880 (map code 8) that differed from the maps of 1864-1873 (map code 6) and 1888-1903 (map code 10). The former two adopted a projection cartographic technique with a scholarly appearance, while the latter two were made with a traditional grid system and more public oriented and intelligible. The lost canals appeared in the centre two maps, and there were less than 8 years between the disappear-emerge, redisappear-reemerge process.

The map of 1864-1873 coded 6 was the first among all available maps that set the plan slightly acclivitous adapted to the actual orientation, and the latter map of 1888-1903 coded 10 was almost the same, equipped with a grid and more detail. Both of these utilized to a certain degree the cartography projection technique, and were supposed to be treated as maps of the scientific phase, or set out from an official purpose. Besides the omission of the agricultural canals, there were relatively less waterways even in the urban area where there were bridges marked without canals.

From textual records about the status of waterways, they had not been in a good condition due to continual disturbance: being occupied, blocked and polluted along with increased population or the sudden destruction of war. The cartographers of map coded 6 and 10 may be truthful, it was highly possible that there was actually no water in the canals and they drew from the condition on the ground (except the agriculture canals at both the north and south ends of the city).

Hence, to judge the reality of a historical map, at least 3 points should be examined carefully: a) The purpose of the map, official, public or tourist oriented; b) The cartographical method, traditional or scientific; c) The cartographer. It is where the sentimental plus comes from, and then a survey into the text is called for.

\subsection{Further work}

As geo-information beside waterways collected during the process of unification of historical maps is discussed little in this paper, a further work could be a synthesis further analysis will enrich the production of this documentation work and make it a meaningful further work. 


\section{REFERENCES}

\section{References from Books:}

Qu, Weizu，2007.11.篗.,慰祖, ed. 蘇州河道志. 長春: 吉林人 民出版社

Zhang, Yinglin, 2004.6.張., 英霖, 蘇州市地方誌編纂委員會 辦公室< su zhou shi di fang zhi bian zuan wei yuan hui ban gong shi>, 蘇州博物館<su zhou bo wu guan>, and 蘇州碑刻博 物館 $<$ su zhou bei ke bo wu guan>, eds. 蘇州古城地圖集 $=$ the Atlas of Ancient Suzhou. 蘇州: 古吳軒出版社<gu wu xuan chu ban she>

Suzuki, Mituru,1992. 鈴木, 充. 中國 蘇州市の住宅地形成の 研究財団法人住宅総合研究財団 助成研究 No.18816

Ricoeur, Paul, 2004. Memory, History, Forgetting Translated by Kathleen Blamey and David Pellauer. Chicago: University Of Chicago Press.

Lefebvre, Henri, 2006. Writings on Cities, edited by Eleonore Kofman, Elizabeth Lebas. 9th ed. Cambridge, Mass: Blackwell.

References from Gazetteer: (see appendix for date)

"永樂蘇州府志 Yongle Gazetteer of Suzhou Prefecture .1408." Chap. 5, in 永樂大典方志輯佚., Edited by Rong 馬. Ma 蓉, wen 鐘. Zhong 文, Luan, Gui ming 欒, 貴明 and Zhang, Chen shi 張, 忱石. 北京: 中華書局, 2004.4.

Cao, Yun yuan 曹, 允源, and Li, gen yuan 李, 根源. "民國吳縣 志 Minguo Gazetteer of Suzhou Prefecture .1933." in 中國地方 誌集成. Vol. 江蘇府縣志輯 ; 11-12. 南京: 江蘇古籍出版社, 1991.6.

Fan, Cheng da 范, 成大, and Lu, Zhen yue 陸, 振获. "紹定吳郡 志 Shaoding Gazetteer of Wu County .1229." in 江蘇地方文獻 叢書., Edited by zhengxing 薛正興 Xue. 南京: 江蘇古籍出版 社, 1999.8 .

Huang, Fu fang 皇, 甫汸. "隆慶長洲縣志 Longqing Gazetteer of Changzhou County .1571." in 天一閣藏明代方志選刊續編. Vol. 23. 上海: 上海書店, 1990.12 .

$\mathrm{Li}$, Guang xiang 李, 光祥, and $\mathrm{Gu}, \mathrm{Yi}$ lu 顧, 詒祿. "乾隆長洲 縣志 Qianlong Gazetteer of Changzhou County .1753." in 中國 地方誌集成. Vol. 江蘇府縣志輯; 13. 南京: 江蘇古籍出版社, 1991.6.

Li, Ming wan 李, 銘皖, Tan, Jun pei 譚, 鈞培, and Feng, Gui fen 馮, 桂芬. "光緒蘇州府志 Guangxu Gazetteer of Suzhou Prefecture .1882." in 中國地方誌集成. Vol. 江蘇府縣志輯; 710. 南京: 江蘇古籍出版社, 1991.6.

Lu, Guang wei 陸, 廣微, and Cao, Lin di 曹, 林娣. "唐吳地記 Tang Gazetteer of Wu County .875-888." in 江蘇地方文獻叢 書., Edited by zhengxing 薛正興 Xue. 南京: 江蘇古籍出版社, 1999.8.

Lu, Xiong 盧., 熊. "洪武蘇州府志 Hongwu Gazetteer of Suzhou Prefecture .1379." in 中國方志叢書. Vol. 華中地方; 第 153 號. 臺北: 成文出版社, 1970.
Niu, Ruo lin 牛, 若麟. "崇禎呉縣志 Chongzhen Gazetteer of Wu County .1642." in 天一閣藏明代方志選刊續編. Vol. 1519. 上海: 上海書店, 1990.12 .

Shao, Tai 召, 泰 etc. 乾隆蘇州府志 Qianlong Gazetteer of Suzhou Prefecture .17481748.

Tao, Yue 陶., 嶽. "五代史補. 1012." in 景印文淵閣四庫全書. Vol. 406. 臺灣: 臺灣商務印書館, 1984.

Wang, Ao 王., 鏊. "正徳姑蘇志 Zhengde Gazetteer of Suzhou .1506." in 天一閣藏明代方志選刊續編. Vol. 11-14. 上 海: 上海書店, 1990.12.

Wang, Guo wei 王, 國維. "呉中水利全書 Wu-Zhong Shuili Quanshu (Documents on Water Conservancy in Wu) .1639." in 景印文淵閣四庫全書. Vol. 578. 臺灣: 臺灣商務印書館, 1983-1986.

Yang, Xun ji 楊, 循吉. "嘉靖吳邑志 Jiajing Gazetteer of Wu County .1529." in 天一閣藏明代方志選刊續編. Vol. 10. 上海: 上海書店, 1990.12.

Yuan, Kang 袁., 康. "越絶書 Yue-Jue Shu .25-56." in 四部叢 刊. Vol. 史部. 上海: 商務印書館, 1936.

Zhao, Ye 趙., 曄. "吳越春秋 Wu-Yue Chun-Qiu .58-125." in 江蘇地方文獻叢書., Edited by zhengxing 薛正興 Xue. 南京: 江蘇古籍出版社, 1999.8.

Zhu, Chang wen 朱, 長文. "吳郡圖經續記 . 1084." in 宋元方 志叢刊. Vol. 1. 北京: 中華書局, 1990.5.

蘇州市地方誌編纂委員會, ed. 蘇州市志 Gazetteer of Suzhou City 1995. 南京: 江蘇人民出版社, 1995.

\section{APPENDIX}

A Table of Gazetteers in diachronic order:

\begin{tabular}{|c|c|}
\hline Date & Source of the Literatrue \\
\hline $25-56$ & $\begin{array}{l}\text { Yuan, Kang 袁, 康. "越絶書 Yue-Jue Shu .25- } \\
\text { 56." in 四部叢刊. Vol. 史部. 上海: 商務印書館, } \\
\text { 1936. }\end{array}$ \\
\hline $58-125$ & $\begin{array}{l}\text { Zhao, Ye 趙, 爗. "吳越春秋 Wu-Yue Chun- } \\
\text { Qiu .58-125." in 江蘇地方文獻叢書., Edited by } \\
\text { 薛正興. 南京: 江蘇古籍出版社, } 1999.8 \text {. }\end{array}$ \\
\hline $875-888$ & $\begin{array}{l}\text { Lu, Guang wei 陸, 廣微, and Cao, Lin di 曹, 林 } \\
\text { 娣. " 唐 吳 地 記 Tang Gazetteer of Wu } \\
\text { County .875-888." in 江蘇地方文獻叢書., Edited } \\
\text { by 薛正興. 南京: 江蘇古籍出版社, 1999.8. }\end{array}$ \\
\hline 1084 & $\begin{array}{l}\text { Zhu, Chang wen 朱, 長文. "吳郡圖經續記 } \\
\text { 1084." in 宋元方志叢刊. Vol. 1. 北京: 中華書局, } \\
\text { 1990.5. }\end{array}$ \\
\hline 1229 & $\begin{array}{l}\text { Fan, Cheng da 范, 成大, and Lu, Zhen yue 陸, 振 } \\
\text { 猖. "紹定吳郡志 Shaoding Gazetteer of Wu } \\
\text { County .1229." in 江蘇地方文獻叢書., Edited by } \\
\text { 薛正興. 南京: 江蘇古籍出版社, } 1999.8 \text {. }\end{array}$ \\
\hline
\end{tabular}




\begin{tabular}{|c|c|}
\hline 1397 & $\begin{array}{l}\text { Lu, Xiong 盧, 熊. "洪武蘇州府志 Hongwu } \\
\text { Gazetteer of Suzhou Prefecture .1379." in 中國方 } \\
\text { 志叢書. Vol. 華中地方 ; 第 } 153 \text { 號. 臺北: 成文 } \\
\text { 出版社, 1970. }\end{array}$ \\
\hline 1408 & $\begin{array}{l}\text { "永樂蘇州府志 Yongle Gazetteer of Suzhou } \\
\text { Prefecture .1408." Chap. 5, in 永樂大典方志輯 } \\
\text { 佚., Edited by Rong 馬. Ma 蓉, wen 鐘. Zhong } \\
\text { 文, Luan, Gui ming 樂, 貴明 and Zhang, Chen shi } \\
\text { 張, 忱石. 北京: 中華書局, 2004.4. }\end{array}$ \\
\hline 1506 & $\begin{array}{l}\text { Wang, Ao 王, 鏊. "正徳姑蘇志 Zhengde } \\
\text { Gazetteer of Suzhou .1506." in 天一閣藏明代方 } \\
\text { 志選刊續編. Vol. 11-14. 上海：上海書店, } \\
\text { 1990.12. }\end{array}$ \\
\hline 1529 & $\begin{array}{l}\text { Yang, Xun ji 楊, 循吉. "嘉靖吳邑志 Jiajing } \\
\text { Gazetteer of Wu County .1529." in 天一閣藏明代 } \\
\text { 方志選刊續編. Vol. 10. 上海：上海書店, } \\
\text { 1990.12. }\end{array}$ \\
\hline 1571 & $\begin{array}{l}\text { Huang, Fu fang 皇, 甫汸. "隆慶長洲縣志 } \\
\text { Longqing Gazetteer of Changzhou County .1571." } \\
\text { in 天一閣藏明代方志選刊續編. Vol. 23. 上海: } \\
\text { 上海書店, 1990.12. }\end{array}$ \\
\hline 1639 & $\begin{array}{l}\text { Wang, Guo wei 王, 國維. "兌中水利全書 Wu- } \\
\text { Zhong Shuili Quanshu (Documents on Water } \\
\text { Conservancy in Wu) .1639." in 景印文淵閣四庫 } \\
\text { 全書. Vol. 578. 臺灣: 臺灣商務印書館, 1983- } \\
\text { 1986. }\end{array}$ \\
\hline 1642 & $\begin{array}{l}\text { Niu, Ruo lin 牛, 若麟 "崇禎兌縣志 Chongzhen } \\
\text { Gazetteer of Wu County .1642." in 天一閣藏明代 } \\
\text { 方志選刊續編. Vol. 15-19. 上海：上海書店, } \\
\text { 1990.12. }\end{array}$ \\
\hline 1748 & $\begin{array}{l}\text { Shao, Tai 召, 泰 etc. 乾隆蘇州府志 Qianlong } \\
\text { Gazetteer of Suzhou Prefecture.1748,1748. }\end{array}$ \\
\hline 1753 & $\begin{array}{l}\mathrm{Li} \text {, Guang xiang 李, 光祥, and Gu, Yi lu 顧, 詒祿. } \\
\text { " 乾 隆 長 洲 縣志 Qianlong Gazetteer of } \\
\text { Changzhou County .1753." in 中國地方誌集 } \\
\text { 成. Vol. 江蘇府縣志輯 ; 13. 南京: 江蘇古籍出 } \\
\text { 版社, 1991.6. }\end{array}$ \\
\hline 1883 & $\begin{array}{l}\text { Li, Ming wan 李, 銘皖, Tan, Jun pei 譚, 鈞培, } \\
\text { and Feng, Gui fen 馮, 桂芬. "光緒蘇州府志 } \\
\text { Guangxu Gazetteer of Suzhou Prefecture .1883." } \\
\text { in 中國地方誌集成. Vol. 江蘇府縣志輯 ; 7-10. } \\
\text { 南京: 江蘇古籍出版社, 1991.6. （馮, 桂芬撰於 } \\
1869 \text { 年, 李、譚修編） }\end{array}$ \\
\hline 1933 & $\begin{array}{l}\text { Cao, Yun yuan 曹, 允源, and Li, gen yuan 李, 根 } \\
\text { 源. "民國吳縣志 Minguo Gazetteer of Suzhou } \\
\text { Prefecture .1933." in 中國地方誌集成. Vol. 江蘇 } \\
\text { 府縣志輯 ; 11-12. 南京: 江穌古籍出版社, } \\
\text { 1991.6. }\end{array}$ \\
\hline 1995 & $\begin{array}{l}\text { 蘇州市地方誌編纂委員會, ed. 蘇州市志 } \\
\text { Gazetteer of Suzhou City 1995. 南京: 江穌人民出 } \\
\text { 版社, 1995. }\end{array}$ \\
\hline 2007 & $\begin{array}{l}\text { Qu, Weizu 翟.,慰祖, ed. 蘇州河道志. Gazetteer } \\
\text { of Suzhou Waterways 長春: 吉林人民出版社, } \\
\text { 2007.11. }\end{array}$ \\
\hline
\end{tabular}

